\title{
Accessibility and ergonomic analysis for banking cash
}

\author{
Ms. Kaizer, $\mathrm{A}^{\mathrm{a}, \mathrm{b}, *}$, Ramos, $\mathrm{F}^{\mathrm{a}}$ and Ferro, $\mathrm{E}^{\mathrm{c}}$ \\ ${ }^{a}$ NR Work Safety and Health at Work email: kaizer@nrwork.com.br. \\ ${ }^{\mathrm{b}}$ TN Móveis - Industry and Trade of Furniture and Commercial Premises \\ ${ }^{\mathrm{c}}$ ERGOBRASIL Consulting in Ergonomics
}

\begin{abstract}
Ergonomics and accessibility in banking has been the subject of numerous discussions, and in this work proposed by the partnership of companies and NR TN Mobile Work Safety and Occupational Medicine, aimed to analyze the service box and propose the development of a project to the teller accessible account of both the legal aspects regarding the factors inherent in banking, focusing primarily on the interface of the worker and the client user.
\end{abstract}

Keywords: Accessibility, Ergonomics, disabled, Box Bank

\section{Introduction}

People with disabilities have physical disabilities, sensory or mental difficulties were often impossibilities and execution of activities common to others, resulting in the difficulty of shifting from one place to another. Given this, it must be the use of equipment that allow for better living, given the barriers of the physical environment.

To this end, the World Health Organization (WHO) states that the disabled person is one who holds a physical impairment, sensory or mental limitation which causes him and puts at a disadvantage in relation to the category of people considered "normal" (Ministry of Health, 1993).

For those suffering from restriction, the simple act of leaving home means a challenge, especially because cities do not have adequate infrastructure for the disabled. In general, where lack of proper planning, the predominant behavior is to adapt a building already built and does not consider these difficulties at that stage yet.

It must, however, these guys ensure the exercise of effective citizenship and social life through the exercise of freedom and autonomy to come and go.

The Constitution guarantees the right to work, education, health, leisure. It is therefore necessary to ensure the displacement resulting from these activities (Constitution, 1998).

And clearly conceptualize words or phrases to describe certain situations or characteristics can contribute much to re-direct the actions of intervention. For some understanding by society eventually result in actions that discriminate attitudes instead of contributing to social inclusion of disabled people.

The word disability, for example, is often associated with disability and handicap, and disability is understood as a loss or abnormality of structure or function of psychological, physiological or anatomical structure, temporary or permanent, and disability as a restriction on the ability to perform activities considered normal for humans, due to a disability. Now disadvantage is understood as a loss resulting from an impairment or disability, which prevents the performance of roles (AMARILIN et al, 2000).

Although this discussion we can add the word limitation, arising from a disability or not, but often associated with situations of health and illness, lifecycle phase, physical characteristics. The acceptance of this term greatly increases the visibility of the number of people who are permanently or temporarily limited in their access to basic health services.

\footnotetext{
${ }^{*}$ Corresponding author. E-mail: editorial@iospress.nl. Check if the checkbox in menu Tools/Options/Compatibility/Lay out footnotes like Word 6.x/95/97 is selected if you make a footnote for the corresponding author.
} 
In all, the ergonomics, the science of the human interface with the environment where it is located, whether at work, at home or in any other activity gained a greater focus on the disabled when the society has to care about accessibility and social inclusion of the same.

According BRAZIL (1994, 1998), accessibility is defined as conditions of possibility and power to use, with security and autonomy, space, furniture and urban equipment, the buildings, transport and postal systems and media for people with disabilities or reduced mobility.

Accessibility makes up the concept of citizenship in which individuals have rights guaranteed by law that must be respected, however, many of these rights are hindered by social and architectural barriers (Manzini et al., 2003). A built-when accessible to all, is able to offer equal opportunities to all users (Bittencourt et al., 2004).

And by Brazilian law, any person, including those with disabilities are entitled to access to education, health, leisure and work. Thus, people should be seen as equals, thus implying the recognition and meet their specific needs (Andrade et al., 2007). But when dealing with accessibility, we must not only remind us of people with disabilities, we also have another contingent, the third age.

On this perspective, reflections on the difficulties of access by physical barriers are healthy, they contribute to the rethinking of practices and proposing actions that could contribute to the promotion of health and quality of life of these individuals, promoting coexistence and transforming attitudes and behaviors, interfering with interpersonal relationships and behaviors.

And the theme was discussed earlier that we turn our attention to analyze the accessibility of tellers, since this service for today's society has become indispensable regardless of social class, gender, age or profession.

\section{Objective}

This paper presents how to evaluate ergonomic conditions and accessibility for tellers, and from this develop a prototype of furniture to be tested and deployed in bank branches.

\section{Methodology}

\subsection{Bibliografia}

Initially it was based on a literature covering issues of accessibility inherent in the second Brazilian Association of Technical Standards - NBR 9050. To determine the measures, dimensions and areas of operational ranges of furniture.

\subsection{Análise Ergonômica do Trabalho (AET)}

In a second phase was carried out an ergonomic analysis of work (Wisner, 1987; Grandjean, 2005; Read, 2000; Guerin, 2001) analyzing the anthropometric, biomechanical, organizational and accessibility for both the demands on workers with disabilities and such as the elderly.

\subsection{Desenvolvendo o Projeto}

And after the data collection was designed ergonomic furniture in the prototype of the CAD program. Being placed in the same test in locca prior approval.

\section{Results}

After him to collect the data necessary for the design and development of the prototype of the same, we can observe in Figure 1, Figure 2, Figure 3 and Figure 4, measures, dimensions and projected operating range.

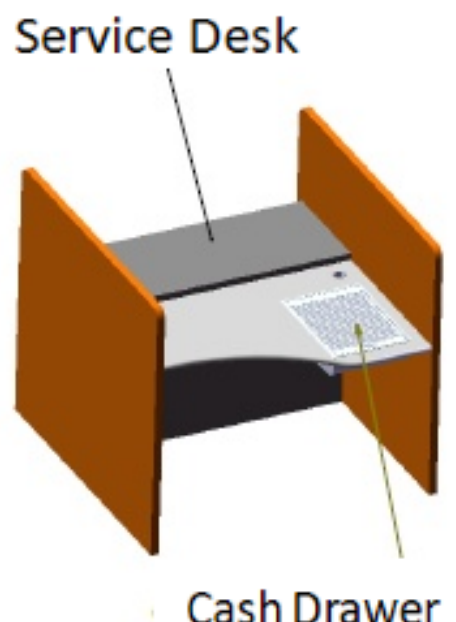

Figure 1. Illustration of the Affordable Housing Banking. 


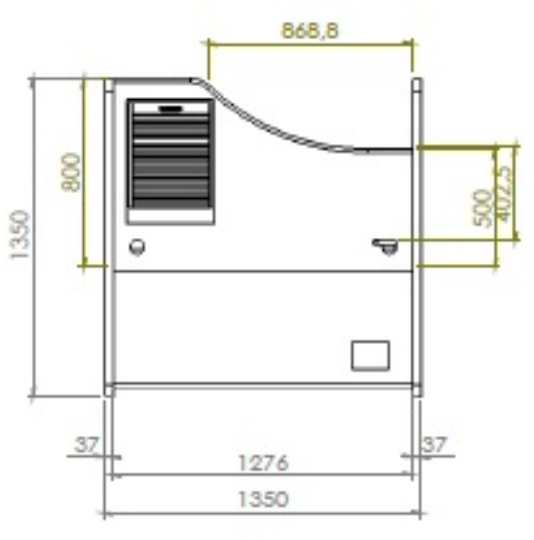

Figure 2. Anthropometric dimensions to accessibility to the range of server and client on the counter of the Bank Affordable Housing.

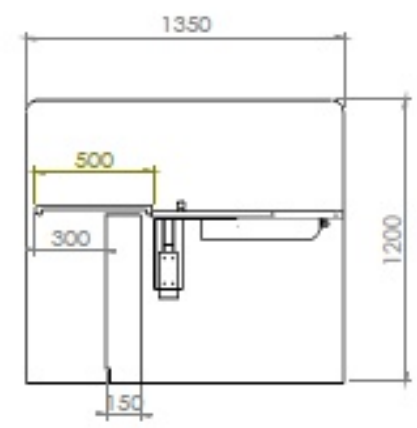

Figure 3. Anthropometric dimensions of the lower accessibility to the server and client on the counter of the Bank Affordable Housing.

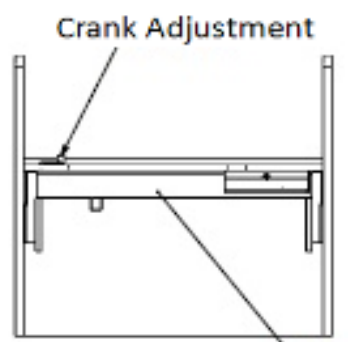

\section{Height Adjustment Mechanism}

Figure 4. Illustration of the height adjustment mechanism for the counter of the Bank Affordable Housing.

After the design phase $\mathrm{d}$ the same project was submitted to a test in locco for 30 days and that it met all expectations proposals for both the worker and for the client.

\section{Discussion e Conclusion}

We note that this study proposed by the company TN furniture to one of its customers and partners to design enabled the workstation thus promoting greater safety, comfort and quality of life for both its workers and for their customers. But we must also note that the accessibility factor in banking is very complex.

For presenting this complex barriers that are often beyond securities, sometimes we encounter architectural barriers, such as ramps, stairs, restrooms, drinking fountains, information booths, dimensions of accessibility in corridors, waiting rooms and so on. More can also be satisfied because an accessibility project should not also include the disabled or elderly population while excluding this job health subjects, where we can all admire. The success of a work has as its accessibility to the major result of the exercise and socialization of all citizens.

\section{References}

[1] Brasil. Constituição (1988). Rio de Janeiro: Senado Federal, 1989. Ministério da Saúde (BR). Atenção à pessoa portadora de deficiência no Sistema Único de Saúde. Brasília, 199.

[2] Brasil. Constituição (1988). Rio de Janeiro: Senado Federal, 1989. Ministério da Saúde (BR). Atenção à pessoa portadora de deficiência no Sistema Único de Saúde. Brasília, 199.

[3] Amaralian MLT, Pinto EB, Ghirardi MIG, Lichtig I, Masini EFS, Pasqualin L. Conceituando deficiência. Rev Saúde Pública, $2000 \mathrm{fev}$; 34(1): 97-103.

[4] Associação Brasileira de Normas Técnicas - NBR 9050. Acessibilidade de pessoas portadoras de deficiências a edificações, espaço, mobiliário e equipamentos urbanos. [online] [acesso 2003 maio 20] Disponível em: http://www.aibr.com/det/sadet/acesso.htm.

[5] BRASIL. Os direitos das pessoas portadoras de deficiência Lei no 7853/89. Decreto n. 914/93. Brasília, DF: Corde, 1994.

[6] BRASIL. PROJETO DE LEI (4767/98). Normas gerais e Critérios básicos para a promoção da acessibilidade das pessoas portadoras de deficiência ou mobilidade reduzida. Brasília, DF, 1998.

[7] MANZINI, E. J. et al.. Acessibilidade em ambiente Universitário: identificação e quantificação de barreiras arquitetônicas. In: MARQUEZINI, M. C. et al. (Org.). Educação física, atividades lúdicas e acessibilidade de pessoas com necessidades especiais. Londrina: Uel, 2003. p.185-192 (Coleção Perspectivas Multidisciplinares em Educação Especial, v. 9).

[8] BITTENCOURT, L. S. et al.. Acessibilidade e Cidadania: barreiras arquitetônicas e exclusão social dos portadores de deficiência física. ANAIS DO $2^{\circ}$ CONGRESSO BRASILEIRO DE EXTENSÃO UNIVERSITÁRIA, 2, Belo Horizonte, 2004. Anais... Belo Horizonte, 2004. Disponível 
em: $<$ http://www.letras.ufmg.br/educonl/arquivos/anais/congre sso $>$. Acesso em: 3 abr. 2008

[9] ANDRADE, M.S.A.; et al. Pessoas com deficiência rumo ao processo de inclusão na educação superior. 2007. Artigo eletrônico. Disponível em: $<$ http://www.fasb.edu.br/revista/index/php/conquer.article/vie w/pdfinterstitial27/0>. Acesso em: 3 abr. 2008

[10] WISNER, A. Por dentro do trabalho. Ergonomia: método \& técnica, São Paulo: FTD/Oboré, 1987.
[11] GRANDJEAN, E; KROEMER, K... Manual de Ergonomia Adaptando o Trabalho ao Homem, $5^{\text {a }}$-edição, 2005, editora Bookmam

[12]Lida, I. Ergonomia - Projeto e Produção 5ª- edição, 1990, Editora Edgard Blücher.

[13] GUÉRIN, et al. Compreender o trabalho para Transforma-lo, $2^{\mathrm{a}}$ - edição, 2001, Editora Edgard Blücher. 